\begin{tabular}{llllllllllll} 
B & I & B & L & I & G & R & A & F & I & A \\
\hline
\end{tabular}

\title{
BIBLIOGRAFIA PRAC PUBLIKOWANYCH KS. PROF. DRA HAB. STANISLAWA GRZYBKA
}

\author{
CZESĆ II 1981-1995 \\ (Część I za lata 1948-1980 została opublikowana w RBL 5/1980/)
}

1981

1. Biblia na co dzień. Komentarz do Ewangelii, wyd. III, Kraków 1981, $13-177 ; 283-285$

2. Miłosierdzie Boże w Starym Testamencie. w: Dives in misericordia Tekst i komentarz, Kraków 1981, 83-89

3. Homilie na niedziele Adwentu i okresu Bożego Narodzenia. Rok B, RBL 5 (1981) $321-336$

4. Homilie na niedziele i święta okresu Bożego Narodzenia. Rok B, RBL 6 (1981) $401-416$

5. Jan Paweł - mąż modlitwy, człowiek intelektu, wielki humanista, Róże Maryi 5 (1981) 16-18

6. Stachowiak L., ks., Prorocy - słudzy słowa, Katowice 1980; RBL 2 (1981) 137-139 (rec.)

7. Biblia księgą życia Ludu Bożego. Praca zbiorowa pod red. ks. St. Eacha i ks. M. Filipiaka, Lublin 1980; RBL 5 (1981) 315-318 (rec.)

1982

8. Maryjna katecheza Jana Pawła II. w: Gaude Mater Polonia, Kraków 1982, 276-282

9. Kerygmatyczne wartości czytania Pisma świętego. Przedmowa. w: G. Martin, Czytanie Pisma świętego jako słowa Bożego, Kraków 1982 , $5-10$

10. Homilie na niedziele i święta. Rok C, RBL 3 (1982) 228-240; 4 (1982) $300-320$; 5 (1982) 385-399; 6 (1982) 451-480

11. Swiątynia znakiem obecności Bożej, RBL 4 (1982) 243-251

12. Księga Joba - Wstęp, przekład i komentarz. w: Pismo święte Starego i Nowego Testamentu (Biblia Poznańska), wyd. II, Poznań 1982, $401-468$

13. Biblijna teologia męczeństwa, Gość Niedz. 31 (1982) 4-5

14. Cazelles H., A le recherche de Moise, Paris 1979; RBL 1 (1982) 61-64 (rec.)

15. Praca zbiorowa, Zanim otworzysz Biblię, Poznań 1981; RBL 1 (1982) $64-65$ (rec.)

16. Loska T., SJ, Bóg dla człowieka, Kraków 1981; RBL 5 (1982) 393-384 (rec.)

\section{3}

17. Pierwsza ,ewangelia pracy” w Księdze Rodzaju. w: Ewangelia pracy. Encyklika Jana Pawła II ,Laborem exercens” wraz z komentarzem, Kraków 1983, 70-75

18. Teologiczne podstawy peregrynacji Matki Bożej Częstochowskiej: w: Maryja - matka Narodu Polskiego, Częstochowa 1983, 282-290 
19. Psałterz - księga naszych ludzkich zobowiązań, RBL 1 (1983) 1-9

20. Homilie niedzielne i świąteczne. Rok C, RBL 3 (1983) 243-277; 4 (1983) $353-372 ; 5$ (1983) $434-466$

21. Homilie wielotygodniowe, RBL 1 (1983) 89-96

22. Homilie na okres Wielkanocny, RBL 2 (1983) $177-190$

23. Homilie niedzielne i świąteczne, Wspól. Ambona 1-2 (1983) 75-78; $84-87 ; 136-139$

24. Homilie niedzielne i świąteczne, Materiały Homiletyczne 1983, z. 60, $112-114$; z. $63,66-69$; z. 65 n, $72-75$

25. Harrington W. J., Klucz do Biblii, W-wa 1982; RBL 1 1983) 56-58 (rec.)

\section{4}

26. Biblia na co dzień. Komentarz do Ewangelii, wyd. IV, Kraków 1984; $13-177 ; 283-285$

27. „Wierzcie w Ewangelię” (Mk 1, 15), Homilie na rok B, Kraków 1984, 236

28. Kerygmatyczne wartości czytania Pisma świętego. Przedmowa. w: G. Martin, Czytanie Pisma świętego jako słowa Bożego, wyd. II, Kraków 1984, 5-10

29. Homilia wygłoszona na pogrzebie śp. ks. prof. Stanisława Łacha w dniu 12 czerwca 1983 r., RBL 1 (1984) 2-5

30. Kazanie wygłoszone na pogrzebie ks. prof. W. Smereki - 2 września 1988 r., RBL 2 (1984) 99-102

31. Pochyleni nad stronicami Biblii, RBL 2 (1984) $150-159$

32. Formuła wprowadzająca do Dekalogu (Wj 20,2; Pwt 5,6). w: Służyć prawdzie i miłości. Pamięci księdza biskupa dra Stefana Bareły III ordynariusza częstochowskiego, Częstochowa 1984, 223-233

\section{5}

33. Metodologia teologii biblijnej, RBL 2 (1985) 89-99

34. Przedmowa. w: Wiem komu zawierzyłem. Katechizm dla dorosłych, Kraków 1985, 5-6

\section{6}

35. Formy apostolatu Pismem świętym, RBL 1 (1986) 55-69

36. Homilie niedzielne, Współcz. Ambona 1 (1986) 66-68

37. Idea pielgrzymowania w Piśmie świętym. Niedziela 15 (1986) 1.6

38. Wstęp. w: ks. Stanisław Wiśniowski, Błogosławiona Maria Teresa Ledóchowska - życie i działalność, Kraków 1986, 5-6

39. „Nawracajcie się, bo bliskie jest królestwo niebieskie” (Mt 4,17). Homilie na rok A, Kraków 1986, 230

40. Dzieje Przymierza. Biblia dla młodzieży, W-wa 1985; RBL 1 (1986) 79 -80 (rec.)

41. Bartnicki R., ks., Uczeń Jezusa jako głosiciel Ewangelii, tradycja i redakcja Mt 9,35-11,1, W-wa 1985; RBL 2 (1986) 174-175 (rec.)

\section{7}

42. Typologia Eucharystii w Starym Testamencie. w: Eucharystia źródłem życia, Kraków 1987, 7-17

43. Najświętsza Maryja Panna w Piśmie świętym, Jasna Góra 2 (1987) $33-40$

44. Eucharystia zobowiązuje do praktykowania chrześcijańskiego miłosierdzia, Niedziela 32 (1987) 1. 4 
45. Kudasiewicz J. ks., Biblia - Historia - Nauka, Kraków 1987; RBL 3 (1987) 268-270 (rec.)

46. Wiśriowski St., ks., Błogosławiona Maria Teresa Ledóchowska - życie i działalność, Kraków 1986; Niedziela 33 (1987) 8 (rec.)

47. Kręt H., Dwór królewski Jadwigi i Jagiełły, Kraków 1987; Niedziela 33 (1987) 8 (rec.)

48. Praca zbiorowa, Eucharystia źródłem życia, Kraków 1987; Niedziela 36 (1987) 8 (rec.)

49. Jelonek T. ks., Biblijna historia zbawienia, Kraków 1987; Niedziela 40 (1987) 8 (rec.)

50. Kudasiewicz J., Jezus historii a Chrystus wiary, Lublin 1987; RBL 5 (1987) $542-544$ (rec.)

51. Mszał z czytaniami, Katowice 1987; RBL 5 (1987) 453-454 (rec.)

52. Lohfink G., Rozumieć Biblię, W-wa 1987; RBL (1987) 542-544 (rec.)

53. Przedmowa. w: Grela K., Konkordancja Nowego Testamentu, Kraków 1987 ; t. I, $5-6$

\section{8}

54. Maryja przed Chrystusem na horyzoncie dziejów zbawienia. w: Matka Odkupiciela. Komentarz do encykliki „Redemptoris Mater”, Kraków 1988, 33-41

55. Z obfitości serca usta mówią. Homilie na rok C, Kraków 1988, 199

56. Komentarz do encykliki o Matce Bożej, Niedziela 29/1988 6 (rec)

57. Wpływ lektury Pisma świętego na formację religijną rodziny, CzST t. $15-16,1987-1988,181-192$

1989

58. Biblijne inspiracje encykliki Jana Pawła II „Redemptoris Mater”, RBL 4 (1989) 278-289

59. „Przygotujcie drogę Panu. Jemu prostujcie ścieżki” (Mt 3,3). Homilie na rok A. Kraków 1989, 202

60. Problematyka życia rodzinnego w Księdze Tobiasza, RBL 2 (1989) $119-124$

61. Przedmowa, w: ks. G. Siwek, Spotkania w Słowie, Kraków 1989, 3-4

62. Nowa konkordancja biblijna, Niedziela 7 (1989) 7 (rec.)

63. A. Ricciardi, Franciszka Siedliska, Rzym 1987; RBL 2 (1989) 155-156 (rec.)

64. Fr. Hengsbach, Ich der Mitälteste, Essen 1974; RBL 5 (1989) 401-403 (rec.)

65. Sobór drogowskazem, Kalwaria Zebrzydowska 1989; RBL 4 (1989) $319-320$ (rec.)

1990

66. Czy Dekalog jest dziś aktualny?, Tygodnik Katolicki (Londyn), 8

67. Czy Dekalog jest jeszcze dziś aktualny?. Katowice 1990, 8

68. Eucharystia w kontekście Ostatniej Wieczerzy, Katowice 1990, 8

69. Godność i prawa osoby ludzkiej w świetle niektórych encyklik Jana Pawła II, Katowice 1990, 8

70. Pascha Starego Testamentu zapowiedzią nowej Paschy, Katowice 1990, 12

71. Wiara w zmartwychwstanie ciał w Starym Testamencie, Katowice 1990,8 
72. Wpływ posoborowej odnowy liturgicznej na powstawanie homiletycznych komentarzy biblijnych. w: Prasa i książka religijna. Materiały z IV Warmińskich Dni Duszpasterskich w Olsztynie, Olsztyn 1990, 107-118

73. T. Olszański ks., W światłach Męki Pańskiej, Kraków 1990; RBL 3-6 (1990) 181-182 (rec.)

74. T. Olszański, ks., W światłach Męki Pańskiej, Niedziela 11 (1990) 5 (rec.)

\section{1}

75. Człowiek w Starym Testamencie, w: Vademecum biblijne, Kraków 1991, cz. IV, 111-136

76. Chleb na życie wieczne, Nasze Słowo (Dwutygodnik Polskiej Misji Katolickiej w Niemczech) 16 (1991) 5

77. Instytut Teologiczny w Częstochowie. w: Instytut Teologiczny w słuzbie diecezji częstochowskiej, Częstochowa 1991, 17-25

78. Obraz Boga w Starym Testamencie. w: Vademecum biblijne, Kraków 1991, cz. IV, 94-109

79. Obraz człowieka w Starym Testamencie, Kraków 1991, 32

80. Pascha Starego Testamentu zapowiedzią nowej Paschy. w: Instytut Teologiczny w służbie diecezji częstochowskiej, Częstochowa 1991, $59-71$

81. Wpływ lektury Pisma świętego na formację religijną rodziny. Częst. Studia Teolog., t. XV-XVI, 1991, 181-182

82. Zjednoczeni z Chrystusem, Nasze Słowo 17 (1981) 4

83. Zmartwychwstanie w świetle ksiąg Starego Testamentu. w: Vademecum biblijne, Kraków 1991, cz. IV, 154-165

84. Źródła kryzysu wiary, Nasze Słowo 17 (1991) 5

84. Przedmowa. w: Instytut Teologiczny w służbie diecezji częstochowskiej, Częstochowa 1991, 5-6

1992

86. Fr. König kard. - J. Kramer, Żyć wiarą dzisiaj. Lublin 1992; Częst. Stud. Teolog., t. XIX-XX, 1991-1992, 471-473 (rec.)

87. Małysiak Al., bp, Szukamy Boga. Wczoraj i dziś duszpasterza. Kraków 1991; Homo Dei 2-3 (1992) 147-149 (rec.)

88. Witaszek G., ks., Niesprawiedliwości społeczne i ich konsekwencje w myśli religijnej proroka Amosa. Tuchów 1992; Częst. Studia Teolog., t. XIX-XX, 1991-1992, 468-471 (rec.)

89. Wojtczak A., OFMConv, Swięty Maksymilian M. Kolbe. Roma 1992; Częst. Studia Teolog., t. XIX-XX, 1991-1992, 465-468 (rec.)

\section{3}

90 Biblia uczy modlitwy. Homilia na XVII niedzielę zwykłą. Materiały Homiletyczne $7-8$ (1993) $66-69$

91. Homilie. Nasze Słowo (Dwutygodnik Misji Katolickiej w Niemczech) 13 (1993), 14 (1993), 15 (1993), 18 (1993), 20 (1993), 21 (1993)

92. Nasza wiara w zmartwychwstanie. Homilia na 32 . niedzielę zwykłą. Materiały Homiletyczne 11-12 (1993) 72-75

93. Rola i znaczenie dziecka w rodzinie w świetle ksiąg Starego Testamentu. Wiad. Arch. Częst. 8-10 (1993) 274-281

94. Sp. o. mgr Jan Fijałkowski - Wspomnienie pośmiertne. Wiad. Prowincji MBNP OO. Franciszkanów w Polsce 4 (1993) 67-69 
95. Bednarz M., ks., Zasłuchani w Słowo Pana. Tarnów 1992; Homo Dei 1 (1993) 68-69 (rec.)

96. Biblia w nauczaniu chrześcijańskim. Praca zbiorowa pod red. J. Kudasiewicza. Lublin 1991; RBL 1 (1973) 45-47, Homo Dei 3 (1993) $109-107$

97. Grudniok Fr., ks., Nazwał nas przyjaciółmi. Katowice 1991; Homo Dei 3 (1993) 107-108 (rec.)

98. Słowo wstępne. w: ks. A. Długosz, Pismo święte naszym przyjacielem. Częstochowa 1993, 7-9

\section{4}

99. Homilie. Nasze Słowo 1 (1994), 3 (1994), 9 (1994), 10 (1994)

100. Kiedy złe rzeczy dzieją się dobrym ludziom. Niedziela 3 (1994) 16

101. Nowy biskup pomocniczy w Częstochowie. Nasze Słowo 6 (1994)

102. Pielgrzymowanie z Maryją. Niedziela 39A (1994) 16

103. Wpływ lektury Pisma świętego na duchową formację chrześcijanina. RBL 3 (1994) 197-204

104. Brzegowy T. ks., Prorocy Izraela. Tarnów 1994; RBL 3 (1994) 219-221 (rec.)

105. Grudniok Fr., ks., Skarb cierpienia. Wrocław 1994; RBL 2 (1994) 133-135 (rec.)

106. Kushner H. S., Kiedy złe rzeczy zdarzają się dobrym ludziom. W-wa 1993; RBL 1 (1994) 64-65 (rec.)

107. Siudy T., ks., Refleksje Maryjne. Częstochowa 1994; RBL 4 (1994) 288-286 (rec.)

108. Zapatrzeni w szczęśliwość wieczną. Rycerz Niepokalanej (wersja włoska) 11 (1994) 333

\section{5}

109. Kerygmatyczne wartości Pisma św. w świetle ewangelizacji współczesnego świata. RBL 1 (1995) 27-33

110. Kim jest zakonnica? (Recenzja książki ks. Fr. Grudnioka, Która wiele umiłowała). Niedziela 47A (1995) 16

111. Uświęć ich w Prawdzie (J 17,17). Homilie niedzielne - Rok A. Kraków 1995, 293

Kraków

zestawił KS. TADEUSZ MATRAS

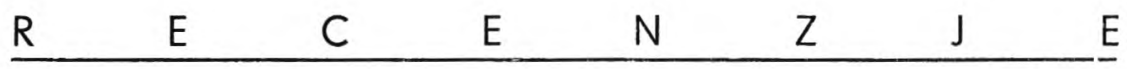

KS. JOZEF $€ A C H, ~, Z$ myśla o rodzinie. Komentarz biblijno-ascetyczny do czytań ślubnych", Wyd. Biblos, Tarnów 1995, stron 169.

Komentarz swój podzielił Autor na cztery części. W cz. I omówił czytania ślubne ze Starego Testamentu, (ss. 9-50), w cz. II czytania z tekstów Nowego Testamentu (głównie listy Pawłowe), zaś w cz. III zatytułowanej ,pełnia łaski i prawdy” przekazał i omówił czytania z ewangelii 